\title{
Brand Value Assessment in Terms of Contemporary Global Challenges
}

\author{
Maria Misankova $^{1}$, Jana Kliestikova ${ }^{2}$, Anna Krizanova ${ }^{3}$, Tatiana Corejova ${ }^{4}$ \\ 1, 2, 3, ${ }^{4}$ Department of Economics, Faculty of Operation and Economics of Transport and Communications, \\ University Ahmed of Zilina, Zilina, Slovak Republic \\ E-mails: ' ${ }^{m a r i a . m i s a n k o v a @ f p e d a s . u n i z a . s k ~(c o r r e s p o n d i n g ~ a u t h o r) ; ~}{ }^{2} j a n a . k l i e s t i k o v a @ f p e d a s . u n i z a . s k$; \\ ${ }^{3}$ anna.krizanova@fpedas.uniza.sk; ${ }^{4}$ tatiana.corejova@fpedas.uniza.sk
}

Received 12 February 2017; accepted 05 April 2017

\begin{abstract}
Brand represents one of the most important assets of the company. Brand-managing activities are typically related to brand positioning and integration with marketing campaigns, and can involve complex decisions. The branding of an organization is indeed a dynamic system with many cause-effect relationships as well as intangible and heterogeneous variables. In order to assess the value of individual brands can be used various models developed worldwide, based on different input data and valuation methodologies. We assume that individual environment in which company operates and consumers' perceptions in different countries influence the ability and usability of these models in other countries. Therefore, we applied chosen well-known brand value models on the set of Slovak companies and validated their assessment ability in specific condition of the Slovak Republic. This was provided by the critical comparison of calculated values with the official values of brands of these companies listed in the Slovak journal. Through this, we pointed out the importance of the development of unique brand value model, which will be constructed in the specific condition of individual countries and highlight the weak assessment ability of foreign models.
\end{abstract}

Keywords: brand, brand value, branding, brand value assessment, Slovak companies, global challenges.

JEL Classification: M31, G31.

Conference topic: Modern Business Management Problems and Perspectives.

\section{Introduction}

Building and managing brand equity is a relatively new managerial discipline on the Slovak market. In todays oversaturated market is increasingly more difficult to attract, reach and above all to get to keep customers for its product. Through the constant technological development in recent years, it is now possible to produce almost anything, competition on the market is huge and it depends on the details and on the little things that can distinguish individual products from each other.

Based on the mentioned above it is clear that the time period of products has been replaced by brands and therefore is conscious building and managing of brand value an important task of every marketing manager. Brand is what affects consumption preferences, contributes to the improvement of our life and provides information around. It is not enough just to build a brand, but management must also understand how promote the vision and identity of brand and through marketing activities help with a proper brand positioning.

Successful branding supplements customer value and can provide protection from price competition and pressures towards commoditization. This involves complex processes which move from satisfying a basic human need to becoming a medium of social exchange and social structuration in advanced societies. Before pointing out the concepts of brand value assessment it is appropriate to consider a general idea of brand and brand equity as a starting point of the presented research. The idea that brand names add value to a product has been always understood by marketers worldwide. However, it was after 1980s that this concept began to be a part of actual asset value of a company. So along this not only the term brand but also the term brand equity became to arise.

So according to Zhang et al. (2007) can be pointed out that measuring brand value has been always a very important issue not only for marketers, but it is also in the interest of financial managers. So in order to evaluate the brand value of individual brands can be applied different methodologies (Huang 2015) developed international in which national environment of the company's economics is not taken into consideration. Furthermore, the valuation ability of most models may vary over time. So we assume that most of the models derived for brand value assessment can only be applied in the selected sector and under the same economic situation for which the tools were originally modelled. Otherwise, these brand value methods provide far fewer accurate results. 
To extend the knowledge on brand value assessment this study attempts to analyse and improve the unpleasant scenarios encountered with the general models through the deep analysis of data of selected brands in the Slovak Republic followed by the comparison of detected values with the official list of brand values published in the Slovak journal.

To achieve these efforts, two research questions were built:

1) Are there differences between calculated values of the brand in comparison to values listed in Slovak journal Forbes?

2) Is the assessment ability of brand value models sufficient according to specifics of Slovak economy?

\section{Previous Research}

Historical analysis of methods and definitions of brand shows that in the literature can be found various approaches to the semiotics of brand which are troubled by the lack of any accepted analytic definition of the phenomenon, as well as capacious, almost metaphysical, extensions which brand becomes identified with semiosis as such, and thus everything is a brand (Manning 2010).

Park et al. (2013) highlights the perception of a brand as a logo which is positively correlated with firm's performance. Similar attituted in which is brand seen as a logo, but in connection with customer perpectives was applied by Machado et al. (2015). On the other side there are studies considering the strong relationship between consumptions vision and formulations of brand attitudes (Chang 2012).

Corporate brand identity management is a key issue for any organisation (Buil et al. 2016). Social identity theory reflecting in brands was proposed by Butgel Tunali (2016) and this can be confirmed by Urde and Greyser (2016) and their new framework representing reputation matrix explaining corporate brand identity. Porter (2013) emphasizes analogies between brand logo, vision and identity as an unseparated parts of brand management.

A different approach is presented by Lemper (2012) who suggests law strategies for more effectively protecting and managing brand names. The legal strategies profiled introduce to a variety of trademark issues that are often overlooked in the management and protection of brand names, even by sophisticated and savvy business people. Analogies between brand and image can be found in work of Sajtos et al. (2015) underlying brand image as the driving force of businesses. According to the stated facts can be assumed that nowadays is brand an unseparated part of products and can be seen in connection with other relevant concepts.

With the level of globalization and fast development of marketing economy, both macroeconomic and microeconomic changes have a nearly immediate impact on individuals. Moral concerns are also gaining global recognition. In earlier times, most authors understood the psychological concepts of a brand by evaluating of the economic value, which is one of the most significant tasks for economic and management science and business practice (Ginevičius, Gudačiauskas 2004).

Stefanovski et al. (2014) underlines the strong correlation between financial management and brand value assessment as in today's global economic societies and open market systems, knowing the true value of brand can help a company in optimising its management actions, create useful marketing strategy and gain further financial benefits. The valuations are also necessary for brand portfolio management, brand architecture, marketing strategy, as well as in some occasions, the brand valuation can ve used to compare the levels of success of various brand strategies and relative performance of marketers (Salinas 2009).

First valuation methods and techniques were developed by the firm Rank Hovis McDougall in collaboration with Interbrand, a consulting firm specialising in brand building. They propose first valuation method assessing the value of a portfolio of brands by developing an early set of metrics based on brand strength. (McAuley 2003) Since that time the brand valuation industry has undergone dramatic changes and various authors of valuation models for commercial brands have been identified.

Evaluation of the brand by considering the cost of developing it during any and all phases of its development is well-known as cost approach. Despite the many limitations and reservations of this method (Zhou 2007), it inspired many studies devoted to the issue of brand value assessment. Fernandez-Barcala and Gonzalez-Diaz (2006) apply a similar view on this approach arguing that the higher the transaction costs, the greater the brand equity. Another widespread method used for the brand value assessment is market approach. Respecting basics of this approach Ahmed and Salah (2009) provide the linkage between customers based brand equity with brand market performance. In spite of difficulties with the appropriate prediction of future income, Wang (2012) proposed discounted income adjusting approach for the network brand value assessment as an important component of network brand building. On the other side the close connection between these approaches was emphasizes by Schultz (2016), who suggested a new approach to determine market brand equity (MBE) impact based on estimations of additional cash flows which might return to the firm as a result of additional investments made in the brand.

Boronos et al. (2016) assess the impact of the brand as an intangible factor on the enterprise value through the systematization of financial and accounting approaches. They have proved the difference in value of equity calculated according to the balance sheet and its market value caused by the hidden (off-balance) capital. 
Combination of the psychological strength of a brand in the mind of its consumers with accepted accounting practices to determine the true financial value of a brand can be found in the Advnced Brand Valuation (ABV) model integrating common marketing research metrics into financial calculations and meets standards for tax and financial reporting purposes (Hupp, Powaga 2004).

Additionally, Romero and Yague (2016) proved that the relationship between brand equity and customer equity have an immanent impact on the brand value and provide its assessment by adopting a brand-customer portfolio approach to enhance company profitability and including evaluation of both, intangible assets and marketing activities. In the same way Salamovska and Todorovska (2016) points out the nature of relationship between marketing assets and marketing equity, especially brand equity according to the both, the theoretical and managerial issues related to the brand valuation and marketing assets assessment.

Versatility of mathematical-statistical methods was confirmed by adoption of theory of fuzzy mathematics and analytic hierarchy process (AHP) to propose a fuzzy evaluation model of brand equity from a customer perspective (Huang 2006). Also Zhou (2006) created a Brand Relationship Index model explaining five-dimension indicator stem for brand evaluation. Similar idea with different method can be found in work of Ferjani et al. (2009) through developing and testing a reduced-form, conjoint methodology for measuring brand equity.

Based on the completion of previous research of brand valuation models it can be stated that some models only estimate material brand value (economic brand valuation models), others uncover customer attitudes and behavior in brand valuation (psychographical and behaviorally-oriented brand valuation models), and still others mostly estimate material brand value also taking into account customer behavior in the viewpoint of brand value. According to these facts Virvilaite and Jucaityte (2008) joined all of them into the complex integrated brand valuation model uniting economic, psychographic and behaviorally oriented brand valuation models.

\section{Methodology}

The data for the study were obtained from the financial statements of selected group of Slovak corporations (Register of financial statements, Ministry of Finance of the Slovak Republic) and covers the period from 2012 to 2015. Similarly, to other countries Slovak financial reporting doesn't include individual evaluation of the brand value. Subsequently, a review of highly valuable brand evaluation models was conducted (similar to Virvilaite, Jucaityte 2008 and according to Kylianova, Lalikova 2010), and the most appropriate and commonly used models were chosen. Namely Royalty savings model and model Brand Value Added. Therefore, we applied chosen brand value models on the set of Slovak companies.

Fundametals of these approaches were applied according to Salinas (2009) to determine the brand value of selected group of Slovak corportions. Both models are based on the discounted future income so the main task was the set of the appropriate discount rate, which can be calculated through various methods. The calculation of discount rate for calculations in this study was provided by the use of: risk free rate, coefficient beta, equity market risk premium. (Grinblatt, Liu 2008) These discount rates were set individually for each evaluated company respecting their economic section and other relevant individual factors.

Royalty savings model determines brand value with respect to the royalty rate that would be payable for the use of the brand if it had to be licensed from a third party. The royalty rates are set on the basis of typical royalty rates charged by competitors who own similar brands operating in the same sector. Brand value according this model is calculated as follows (Eq. (1)):

$$
B V=\frac{S \times R R \times F O \times P A}{C R},
$$

where: $B V$ - annual value of intangible assets (brand value); $S$ - annual sales; $R R$ - royalty rate; $F O$ - obsolescence factor; $C R$ - capitalization rate; $P A$ - proportion of intangible assets to production.

Then the capitalization rate is calculated as follows (Eq. (2)):

$$
C R=\frac{1}{(1+d r)^{t}},
$$

where: $C R$ - capitalization rate; $d r$-discount rate; $t$ - individual time periods.

Model Brand Value Added uses Economic Value Added as the basis for calculation and its supplemented by BVA INDEX that enables the EVA-based calculation of earnings attributable to brand. BVA INDEX is produced through demand driver analysis consisting of ten objectively verifiable key brand performance indicators - time on the market, distribution, market share, market position, rate of sales growth, price additional charge, price elasticita, marketing costs, awareness of advertising and brand awareness. Each indicator is rated by a value from 0 to 10 and final sum is devided by 100 . The value of a brand is then calculated according to Eq. (3): 


$$
B V=\frac{E V A \times B V A I N D E X-T A X}{(1+d r)^{t}}
$$

where: $B V$ - brand value; $E V A$ - economic value added, $B V A I N D E X$ - calculated index $B V A$; $T A X$ - amount of tax; $d r$ - discount rate; $t$ - individual time periods.

Based on the mutual combination of chosen brand value models with three various discount rates were detected six various final values of brands of selected group of Slovak corporations. (see Table 1 and Table 2).

\section{Results}

Results of calcultions of the brand value of selected companies according to the Roayalty Savings Model are shown in the Table 1, where all calculations are provided on the basis of three different discount rates. Gained results are interesting in context of Gollier and Hammitt (2014) who pointed out that the choice of appropriate rate at which one should discount the long-term incomes generated by brand is highly controversial. Results revealed that the brand value of companies based on the Roalty Savings Model according to the discount rate derived from Equity Market Risk Premium is approximately $16 \%$ lower than one derived from Risk Free Rate.

Table 1. Brand value of selected Slovak companies based on the Royalty Savings Model in variants according to different discount rates (Source: self processed)

\begin{tabular}{lccc}
\hline \multicolumn{4}{c}{ Royalty Savings Model } \\
\hline Name of the company & Risk Free Rate & Coefficient Beta & Equity Market Risk Premium \\
\hline Slovenská sporitelı̌na & $183524000,00 €$ & $166696291,16 €$ & $153978806,41 €$ \\
VúB Banka & $137643000,00 €$ & $125022218,37 €$ & $115484104,80 €$ \\
Tatra Banka & $133972520,00 €$ & $121688292,54 €$ & $112404528,68 €$ \\
ESET & $112867260,00 €$ & $102518219,06 €$ & $94696965,94 €$ \\
Slovnaft & $94514860,00 €$ & $85848589,95 €$ & $79299085,30 €$ \\
Matador & $44963380,00 €$ & $40840591,33 €$ & $37724807,57 €$ \\
Zlatý Bažant & $26610980,00 €$ & $24170962,22 €$ & $22326926,93 €$ \\
Rajec & $11929060,00 €$ & $10835258,93 €$ & $10008622,42 €$ \\
Sygic & $7340960,00 €$ & $6667851,65 €$ & $6159152,26 €$ \\
\hline
\end{tabular}

Differences between worked out values according to the table 1 are high and varies between 1,2 million $€$ and almost 30 million $€$. So it is clear that this phenomenom is caused by the use of equity market risk premium as discount rate in comparison with risk free rate, which is lower. Despite quite low values generated on the basis of equity market risk premium as a discount rate, in comparison with other provided calculations, it is considered as the most appropriate method for the detection of discounted future income. (Khorasanee 2009)

On the other side can be assumed that brand values based on the Brand Value Added Model (see Table 2) are lower on average 24 million $€$. However, it is important to highlight such a high difference between values worked out on the basis of risk free rate compared to values calculated on the basis of equity market risk premium. These values are almost $42 \%$ lower.

Table 2. Brand value of selected Slovak companies based on the Brand Value Added Model in variants according to different discount rates (Source: self processed)

\begin{tabular}{lccc}
\hline & \multicolumn{1}{c}{ Brand Value Added Model } \\
\hline Name of the company & Risk Free Rate & Coefficient Beta & Equity Market Risk Premium \\
\hline Slovenská sporitel'ňa & $148257319,12 €$ & $106434943,02 €$ & $86963211,33 €$ \\
VúB Banka & $111192989,34 €$ & $79826207,27 €$ & $65222408,50 €$ \\
Tatra Banka & $108227842,96 €$ & $77697508,40 €$ & $63483144,27 €$ \\
ESET & $91178251,26 €$ & $65457489,96 €$ & $53482374,97 €$ \\
Slovnaft & $76352519,35 €$ & $54813995,66 €$ & $44786053,84 €$ \\
Matador & $36323043,18 €$ & $26076561,04 €$ & $21305986,78 €$ \\
Zlatý Bažant & $21497311,27 €$ & $15433066,74 €$ & $12609665,64 €$ \\
Rajec & $9636725,74 €$ & $6918271,30 €$ & $5652608,74 €$ \\
Sygic & $5930292,76 €$ & $4257397,72 €$ & $3478528,45 €$ \\
\hline
\end{tabular}


According to provided calculations can be summed up that higher values, approximately about $47,5 \%$, were achieved by the Royalty Savings model, but we have to take into consideration requierements on inputs of applied models. On the other side, deeper look on these inputs shows us that Brand Value Added should have a better ability to provide appropriate value assessment in condition of Slovak Republic.

A comparison of the results revealed significant financial differences according to provided calculation of the brand value of selected group of Slovak companies. In response to the actual performance of the Slovak economy (Kotulic et al. 2015), the calculated brand value of particular group of companies is probably excessively large with no apparent macroeconomic cause. Therefore, it is possible to argue that increasingly more managers and even marketers in Slovakia rarely consider the actual value of the brand. Incompetent economic apparatus of the company can produce substantial losses for all parties such as creditors, investors, auditors, financial institutions, stockholders, employees, and customers; this undoubtedly reflects the economics of the countries concerned.

\section{Discussion}

Achieved findings and estimated values of the most valuable brands were compared with the official values of brands of these companies listed in the Slovak journal Forbes. This evaluation is done annually and each year is created a list of the most valuable brands in the Slovak Republic. Our comparison involves average values of brands calculated by two brand value models with the assessment listed in the Slovak Forbes (Table 3).

From the first sight it is clear that average values worked out in the presented study are considerably lower. In case of Roayalty Savings Model it is about $76 \%$ from the estimated value and beyond this in the case of Brand Value Added it is almost $50 \%$ lower. In the term of these results we consider as inppropriate to use selected models of brand value assessment in condition of the Slovak Republic. This is given by the fact that even we have considered the use of three various discount rate probably not all provided calculations are exactly right according to differences between Slovak financial reporting and Interntional Financial Reporting Standards (Tusan et al. 2013).

On the other side there is a lack of information about input data and methods applied for the brand value assessment worked out by Slovak Journal Forbes. We can only assume what type of input data and models they have used for the evaluation. We can assume that they applied foreign model adjusted for Slovak conditions, but from our point of view this is not sufficient according to detected high differences in calculated brand values. Similarly, as we had had to adapt input data for calculations and for the use of selected brand value models we expect that valuation provided by experts in Slovak Forbes was influenced by modification they provided.

Table 3. Comparison of average calculated brand values of selected Slovak companies with brand value assessment provided by Slovak Journal Forbes (Source: self processed)

\begin{tabular}{lccc}
\hline & & \multicolumn{2}{c}{ Average value } \\
\cline { 3 - 4 } Name of the company & Slovak Journal Forbes & Royalty Savings Model & $\begin{array}{c}\text { Brand Value Added Model Equity } \\
\text { Market Risk Premium }\end{array}$ \\
\hline Slovenská sporitel’ňa & $220000000,00 €$ & $183524000,00 €$ & $166696291,16 €$ \\
VÚB Banka & $165000000,00 €$ & $137643000,00 €$ & $125022218,37 €$ \\
Tatra Banka & $160600000,00 €$ & $133972520,00 €$ & $121688292,54 €$ \\
ESET & $135300000,00 €$ & $112867260,00 €$ & $102518219,06 €$ \\
Slovnaft & $113300000,00 €$ & $94514860,00 €$ & $85848589,95 €$ \\
Matador & $53900000,00 €$ & $44963380,00 €$ & $40840591,33 €$ \\
Zlatý Bažant & $31900000,00 €$ & $26610980,00 €$ & $24170962,22 €$ \\
Rajec & $14300000,00 €$ & $11929060,00 €$ & $10835258,93 €$ \\
Sygic & $8800000,00 €$ & $7340960,00 €$ & $6667851,65 €$ \\
\hline
\end{tabular}

Even there have been developed a large number of brand valuation models worldwide, there is a lack of brand value model reflecting economic condition of the Slovak Republic. Based on this we point out that there is a need to develope a unique brand value model, which will be constructed in the specific condition of the Slovak Republic. This is given by the fact that the assessment ability of foreing models is weak and their application in different economics is improper.

\section{Limitations}

According to the provided review of previous research followed by the application of chosen brand value models for the assessment of the brand value of selected Slovak companies and based on the discussion we have detected the main limitation of presented study. Based on these it is the contrast between Slovak financial reporting and International Financial Reporting Standards (IFRS). 
Tusan et al. (2013) detected in their study the major differences between these two approaches, which are according to them the measurement of assets, the recognition of the assets, the method of assets depreciation and the identification of an impairment of assets. On the other side Tumpach et al. (2015) pointed out the risk of adopting IRFS standads in Slovak companies and highlighted an increased risk that the financial statements will not provide a true and fair view of the financial positions and the performance of an accounting entity. Similarly, Wilford (2016) noted the relation between internal control reporting and the accounting standards used by firms (i.e., U.S. and foreign) in their submitted SEC financial statements and also emphasized the correlation between country's specific political factors, rule of law of countries and weaknesses of their financial statements.

Effects of International Financial Reporting Standards (IFRS) adoption was a subject of interest of De George et al. (2016) who proved that IFRS adoption mainly affects: financial reporting quality, capital markets, corporate decision making, stewardship and governance, debt contracting, and auditing. All of these mentioned variables have a significant impact on financial reports and trough this also on the brand value of the company, because these reports represent for the most models the main inputs.

Yurekli (2016) revealed that the corporate cultures and their dimensions adopted by the companies have different impact on their accounting frameworks used. So he assessed how the corporate culture and its dimensions affect the implementation of IFRS, which represents important research in the context of brand valuation as brand and corporate culture have a strong correlation between each other.

Based on the mentioned above we confirmed the detected limitation of this study, which on the other side represents an essential outcome and creates fundamentals for future researches.

\section{Conclusions}

It has been always a hot spot for academics to assess the financial value of brand equity. Meanwhile, brand equity is one of the most controversial topics in marketing researches, since various conclusions have been drawn from varied perspectives, through varied methodologies and for varied purposes. Despite the spectacular growth of the brand value methods, numerous studies have manifested the lack of understanding and apprehensive or incorrect application of these tolls on the part of their different users: corporations, analysts, judges, experts and lenders.

The provided evaluation of brand values of selected Slovak companies confirmed that there are significant differences between calculated values of the brand provided by two chosen methods and also their comparison with values of brands listed in Slovak journal Forbes revealed major contrasts. So based on these and also according to detected limitations of this study we point out that the assessment ability of brand value models constructed worldwide is not sufficient according to specifics of Slovak economy.

There should be a continuous focus on the issue of brand value assessment to ensure business continuity and further sustainable economic development which can be conducted only thorugh the proper valuation methodoly. Therefore, there is a need to develope a unique brand value model, which will be constructed in the specific condition of the Slovak Republic and conclusions of this study will serve as a root for future researches.

\section{Funding}

This work was supported by the Slovak Research and Development Agency [grant number APVV-15-0505]: Integrated model of management support for building and managing the brand value in the specific conditions of the Slovak Republic.

\section{References}

Ahmed, H. T.; Salah, S. H. 2009. Linking customer based brand equity with brand market performance: a managerial approach, Journal of Product \& Brand Management 18(5): 356-366. https://doi.org/10.1108/10610420910981837

Boronos, V.; Plikus, I.; Aleksandrov, V. 2016. Financial and accounting approaches to definition of the intangible factors impact on the value of the company, Economic Annnals - XXI 160(7-8): 121-125.

Buil, I.; Catalan, S.; Martinez, E. 2016. The importance of corporate brand identity in business management: an application to the UK banking sector, BRQ-Business Research Quarterly 19(1): 3-12. https://doi.org/10.1016/j.brq.2014.11.001

Butgel Tunali, S. 2016. Study on the effect of use of luxury brand during the social identityprojection of individuals, Turkish Online Journal of Design Art and Communication 6(3): 326-334. https://doi.org/10.7456/10603100/004

Chang, C. C. 2012. The role of ad-evoked consumption visions in predicting brand attitudes: a relevancy principle model, Psychology \& Marketing 29(12): 956-967. https://doi.org/10.1002/mar.20577

De George, E. T.; Li, X.; Shivakumar, L. 2016. A review of the IFRS adoption literature, Review of Accounting Studies 21(3): 898-1004. https://doi.org/10.1007/s11142-016-9363-1

Ferjani, M.; Jedidi, K.; Jagpal, S. 2009. A conjoint approach for consumer- and firm-level brand valuation, Journal of Marketing Research 45(6): 846-862. https://doi.org/10.1509/jmkr.46.6.846

Fernandez-Barcala, M.; Gonzalez-Diaz, M. 2006. Brand equity in the European fruit and vegetable sector: a transaction cost approach, International Journall of Research in Marketing 23(1): 31-44. https://doi.org/10.1016/j.jiresmar.2006.01.004

Ginevičius, R.; Gudačiauskas, D. 2004. Brand valuation model, Journal of Business Economics and Management 5(3): $143-153$.

Gollier, C.; Hammitt, J. K. 2014. The long-run discount rate controversy, Annual Review of Resource Ecoomics 6: $273-295$. https://doi.org/10.1146/annurev-resource-100913-012516 
Grinblatt, M.; Liu, J. 2008. Debt policy, corporate taxes, and discount rates, Journal of Economic Theory 141(1): 225-254. https://doi.org/10.1016/j.jet.2007.09.009

Huang, J. T. 2006. A study on synthetic fuzzy evaluation method of brand equity, in $8^{\text {th }}$ West Lake International Conference on Small and Medium Business, 15-17 October 2006, Hangzhou, Peoples Republic of China, 1206-1209.

Huang, J. W. 2015. A review of brand valuation method, Journal of Service Science and Management 8: 71-76. https://doi.org/10.4236/jssm.2015.81008

Hupp, O.; Powaga, K. 2004. Using consumer attitudes to value brands: evaluation of the financial value of brands, Journal of Advertising Research 44(3): 225-231. https://doi.org/10.1017/S0021849904040267

Yurekli, E. 2016. How does the corporate culture affect the implementation of IFRS?, International Journal of Contemporary Economics and Administrative Sciences 6(3-4): 86-104.

Khorasanee, Z. 2009. What discount rate should be used to value a cash-flow linked to final salary?, Journal of Pension Economics and Finance 8(3): 351-360. https://doi.org/10.1017/S1474747207003435

Kylianova, D.; Lalikova, L. 2010. Hodnota značky a jej podiel na nehmotnom majetku podniku. ÚPV SR.

Kotulic, R.; Vozarova, I. K.; Nagy, J.; Huttmanova, E.; Vavrek, R. 2015. Performance of the Slovak economy in relation to labor productivity and employment, Procedia Economics and Finance 23: 970-975. https://doi.org/10.1016/S2212-5671(15)00444-X

Lemper, T. A. 2012. Five trademark law strategies for managing brands, Business Horizons 55(2): 113-117. https://doi.org/10.1016/j.bushor.2011.10.005

Machado, J. C.; de Carvalho, L.V.; Torres, A.; Costa, P. 2015. Brand logo design: examining consumer response to naturalness, Journal of Product and Brand Management 24(1): 78-87. https://doi.org/10.1108/JPBM-05-2014-0609

Manning, P. 2010. The semiotics of brand, Annual Review of Anthropology 39: 33-49. https://doi.org/10.1146/annurev.anthro.012809.104939

McAuley, T. 2003. Brand family values, CFO Europe [online], [cited 02 February 2017] Available from Internet: http://ww2.cfo.com/accounting-tax/2003/12/brand-family-values/

Park, C. W.; Eisingerich, A. B; Pol, G.; Park, J. W. 2013. The role of brand logos in firm performance, Journal of Business Research 66(2): 180-187. https://doi.org/10.1016/j.jbusres.2012.07.011

Porter, N. 2013. "Single-minded, compelling, and unique": visual communications, landscape, and the calculated aesthetic of place branding, Environmental Communication - A - Journal of Nature and Culture 7(2): 231-254.

Romero, J.; Yague, M. J. 2016. Marketing assets: relating brand equity and customer equity, Intangible Capital 12(2): 591-618. https://doi.org/10.3926/ic.727

Sajtos, L.; Kreis, H.; Brodie, R. 2015. Image, brand relationships and customer value exploring the moderating role of advertising spending and labour intensity in customer loyalty, Journal of Service Theory and Practice 25(1): 51-74. https://doi.org/10.1108/JSTP11-2013-0261

Salamovska, S. M.; Todorovska, M. 2016. Brand valuation and marketing assets assessment theoretical background vs. contemporary managerial issues, Strategic Management 21(4): 37-44.

Salinas, G. 2009. The international brand valuation manual: a complete overview and analysis of brand valuation techniques and methodologies and their application. John Wiley \& Sons.

Schultz, D. 2016. Market brand equity: lost in terminology and techniques?, Journal of Product and Brand Management 25(6): 507-515. https://doi.org/10.1108/JPBM-07-2016-1260

Stefanovski, L.; Rafajlovski, G.; Naumovski, G. 2014. Trademark valuation - managing intellectual property for strategic marketing and financial benefits, in $8^{\text {th }}$ International Technology, Education and Development Conference, 10-12 March 2014, Valencia, Spain, $5438-5443$.

Tumpach, M.; Mazikova, K.; Kucekova, M. 2015. Boilerplate reporting used by Slovak IFRS submitters, in $10^{\text {th }}$ International Scientific Conference on Financial Management of Firms and Financial Institutions, 7-8 September 2015, Ostrava, Czech Republic, 1334 1339.

Tusan, R.; Banociova, A.; Buleca, J. 2013. Comparison of IFRS and Slovak accounting regulations in the area of accounting and recognition of noncurrent assets, in $6^{\text {th }}$ Annual EuroMed Conference of the EuroMed-Academy-of-Business, 23-24 September 2013, Cascais, Portugal, 2376-2391.

Urde, M.; Greyser, S. A. 2016. The corporate brand identity and reputation matrix - the case of the Nobel Prize, Journal of Brand Management 23(1): 89-117. https://doi.org/10.1057/bm.2015.49

Virvilaite, R.; Jucaityte, I. 2008. Brand valuation: viewpoint of customer and company, Inzinerine Ekonomika-Engineering Economics 1: $111-119$.

Wang, Y. J. 2012. Study on methods of online stores brand value evaluation - the discounted income adjusting approach, in $7^{\text {th }}$ International Conference on System of Systems Engineering (SoSE), 16-19 July 2012, Genoa, Italy, 854-857.

Wilford, A. L. 2016. Internal control reporting and accounting standards: a cross-country comparison, Journal of Accounting and Public Policy 35(3): 276-302. https://doi.org/10.1016/j.jaccpubpol.2015.12.006

Zhang, R. J.; Li, G. F. 2007. Research on the brand value assessment method from many points of view, in 2007 Conference on Systems Science, Management Science and System Dynmics: Sustainable Development and Complex Systems, 19-21 October 2007, Shanghai, Peoples Republic of China, 2869-2876.

Zhou, M. 2007. A new framework to assess the financial value of brand equity - Based on the limitations of historical cost approach and premium price approach, in $4^{\text {th }}$ International Conference on Innovation and Management, 5-6 December 2007, Ube, Japan, 1187 1190.

Zhou, Z. M. 2006. The development of brand relationships index model, in $13^{\text {th }}$ International Conference on Management Science \& Engineering, 5-7 October 2006, Lille, France, 996-1001. 